p. 144

体南器研 笕 X-1

\section{体充会学生の体型について（その V)}

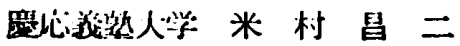

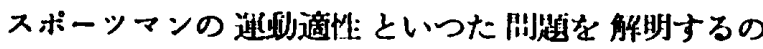

に，その一分野である処の形態学似面の川の一つの体型

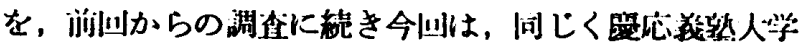

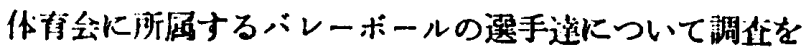
行つてきた。

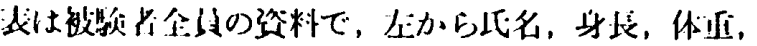

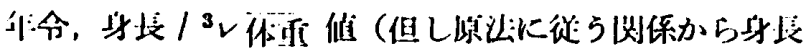
はンイート，何匤はポンドとして山されたもの）敢後に

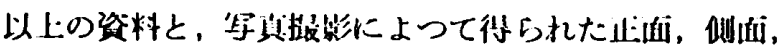
北面からに基ついた体型である。

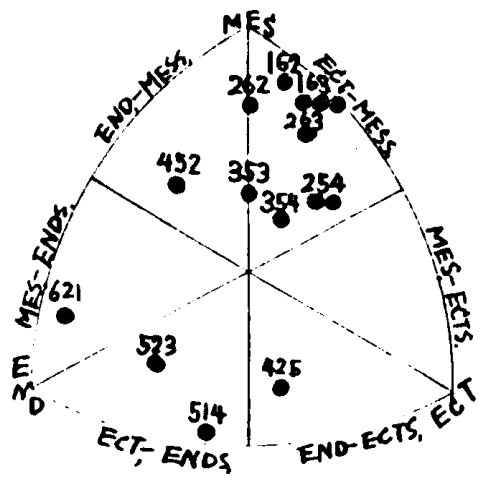

四は被唝者全具の体型を三何分布図型にしたものであ ろ.

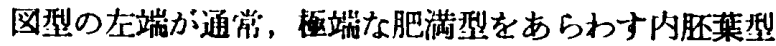

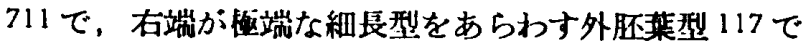

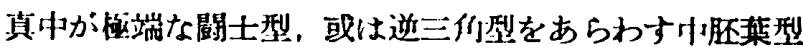
171 で困型の员中がンシランスの妁れた体型 444 となつて いる.

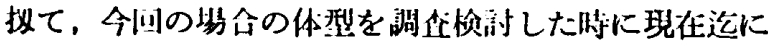
次の小が判つた。

既ち，15名の小4 名を除き彼等の代型の砝んどは检

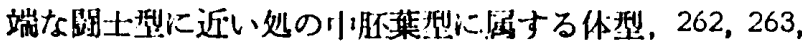

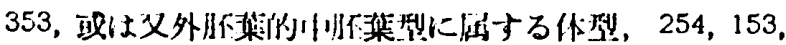

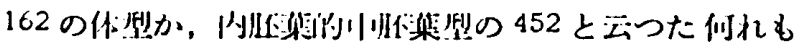

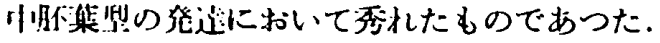

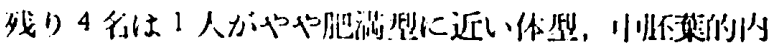

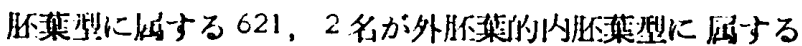

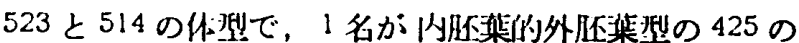
作型であつた。

次にパレーボール選手の体型を全体的にみた垛合に次
の执が判つた。即ち很等の殆んどが川怀葉梨に近い、优型 をしていることである。

然し乍ら 4 名については他と㕮べてなんら機垱伯に少

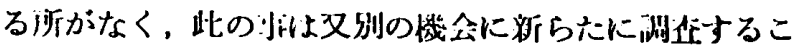
とにした。

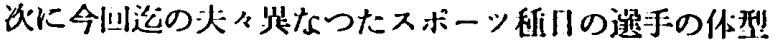

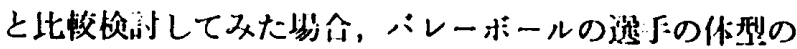

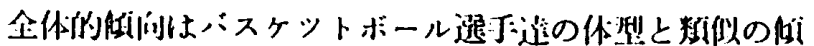

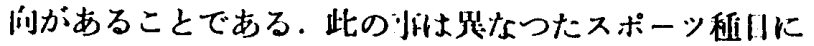

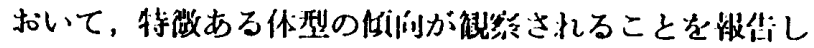

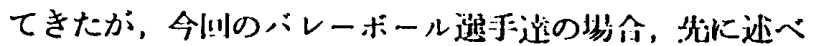

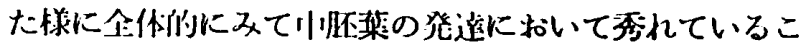

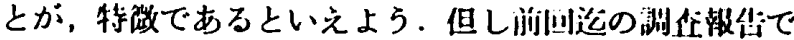

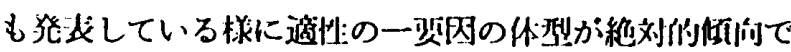
なく，空ろ秀机大選手の川に，例外的休型が必声存在与 ることである。唯，アィリカに括いては邀泳を除いてお

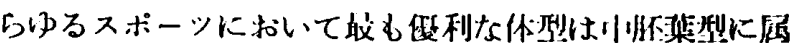
するものであると解告している。

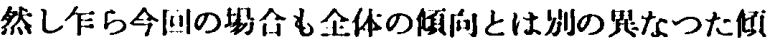

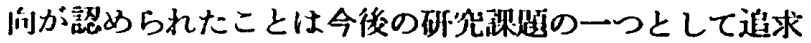
して行きたいと思っている次筑である。

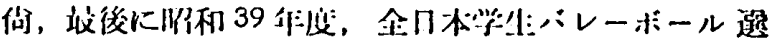

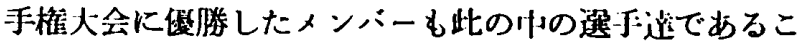
とをつけ加えさせて頂く

\begin{tabular}{c|c|c|c|c|c}
\hline Name & H & W & Age & H/ ${ }^{3}$ W & 作 政 \\
\hline K & 169.8 & 58.5 & 18.10 & 13.25 & 254 \\
N & 177.2 & 68.0 & 18.11 & 13.15 & 354 \\
K & 174.6 & 72.6 & 19.5 & 12.70 & 452 \\
K & 182.7 & 80.5 & 19.10 & 12.80 & 262 \\
T & 177.0 & 61.0 & 20.6 & 13.60 & 425 \\
N & 172.0 & 64.0 & 19.10 & 13.00 & 523 \\
I & 179.2 & 68.5 & 19.10 & 13.30 & 514 \\
S & 174.7 & 68.0 & 20.7 & 12.95 & 263 \\
H & 175.5 & 82.5 & 20.9 & 12.20 & 621 \\
Y & 177.5 & 69.0 & 21.3 & 13.10 & 163 \\
K & 175.8 & 70.0 & 21.7 & 12.90 & 162 \\
K & 177.0 & 70.0 & 21.7 & 13.00 & 352 \\
N & 180.0 & 72.0 & 22.3 & 13.10 & 163 \\
N & 179.5 & 71.0 & 21.0 & 13.10 & 163 \\
S & 180.0 & 68.3 & 20.0 & 12.35 & 254 \\
\hline
\end{tabular}

